\title{
EFFECT OF HEAVY METALS ON SOIL MICROBIAL BIOMASS, AND NEMATODE TROPHIC GROUPS OF A PADDY SOIL AFFECTED BY LONG-RUNNING POLYMETALLIC MINING ACTIVITIES IN GUANGDONG, SOUTHERN CHINA
}

\author{
Zeng, Q. P. ${ }^{1}-$ ZhU, L. A. ${ }^{1 *}-$ WANG, J. Z. ${ }^{2}$ - Cheng, J. ${ }^{1 *}-$ LiU, Y. ${ }^{1}-$ Zhang, H. H. ${ }^{1}-$ \\ LIN, L. W. ${ }^{1}$ \\ ${ }^{I}$ National-Regional Joint Engineering Research Center for Soil Pollution Control and \\ Remediation in South China; Guangdong Key Laboratory of Integrated Agro-Environmental \\ Pollution Control and Management, Guangdong Institute of Eco-Environmental Science \& \\ Technology, Guangdong Academy of Sciences, Guangzhou 510650, China
}

${ }^{2}$ Zhongkai University of Agriculture and Engineering, Guangzhou 510650, China

*Corresponding authors

e-mail:Lazhu@soil.gd.cn;85951452@qq.com

(Received $9^{\text {th }}$ Jan 2020; accepted $6^{\text {th }}$ May 2020)

\begin{abstract}
While the effects of heavy metals on soil organisms are relatively well-documented, the effects of heavy metals caused by long-term sewage irrigation are poorly understood. Therefore, we collected two kinds of soil samples from a paddy field which was irrigated with sewage for more than 20 years (SIA) and the adjacent non-sewage irrigated land as control (NSIA) in Shaoguan, southern China, to assess the long-term effects of multiple metal mining activities on soil microbial biomass, nematode assemblages. The available $\mathrm{Cu}$ and $\mathrm{Zn}$, and the total $\mathrm{Cu}, \mathrm{Zn}, \mathrm{Pb}$ and $\mathrm{As}$ contents in SIA were higher than those in NSIA area by $13.60,7.69,8.56,2.35,2.96$ and 3.11 times on average. Heavy metals stimulated microbial biomass and nematode biomass consumption, which caused a shift in nematode groups, and the mean content of soil microbial biomass carbon (C) and nitrogen (N) in SIA drops by $25.76 \%, 11.10 \%$ compared to the NSIA. Organics showed a positive effect on soil microbial biomass $\mathrm{C}$ and N, with the same response for all types of nematodes, Available $\mathrm{Cu}$ and $\mathrm{Zn}$, and the total $\mathrm{Cu}, \mathrm{Zn}, \mathrm{Pb}$ and $\mathrm{As}$ content in soils exhibited a negative effect on soil microbial biomass $\mathrm{C}$ and $\mathrm{N}$, and each group of nematodes, which reveal that the microbial/nematode activities had been disrupted by the heavy metals.
\end{abstract}

Keywords: long-running polymetallic mining activities, a paddy soil, mine sewage irrigation, heavy metals, soil microbial biomass, nematodes assemblages, effects, southern China

\section{Introduction}

Ore mining making a great contribution to the economy in China, 173 kinds of minerals have been discovered and a variety of metallic minerals (e.g. copper, zinc, lead, etc.) ranked first in the world till 2017 (China Mineral Resources, CMR, 2018). In Shaoguan, a municipality in Guangdong, southern China, polymetallic mining activities have provided livelihoods for local residents since the 1958's in record (Chen, 2012).

Exploitations of ore resource accelerate industrialization process of China and improved Chinese's living standard, but it remains a momentous issue owing to incidences of health problems and environmental degradation (Cortes-Maramba et al., 2006). Ore mining is related to the increasing of soil heavy metals in environment, in general, they are deposited in ore and harmless, yet destabilized heavy metals produced by extraction pose a tremendous threat due to their potential to bioaccumulate, resistant to degradation, last for long period, high in concealment and interfere with biological processes (Heikens et al., 2001). As a result of obsolete equipment, underdeveloped 
technologies, unsubstantial environmental awareness etc., much tailing produced and end up in the soil, atmosphere or river (Getaneh et al., 2006; Martinez et al., 2018). According to statistics, in China, approximately 20,000,000 ha of arable land are polluted by heavy metal, accounting for 1/5 of total arable lands, including 3,300,000 ha of sewage irrigation farmland, especially in red-soil regions, where the soil is worstpolluted (Wen et al., 2008).

Mt. Dabao mine, an old large-scale region for copper exploit before Tang and Song dynasties, abandoned in 1465's, reconstructed in May 1958 and completed in 1975 (Chen, 2012). Ore mining of Mt. Dabao mine was mainly dominated by surface mining and supplemented by underground mining, where the ore is made up of pyrrhotite, pyrite, chalcopyrite, as well as minor components of galena, limonite, chalcocite, calaverite, sphalerite, and native bismuth in mineral deposits (Zhou et al., 2007). Since mining began in 1976, a large amount of acid mine drainages and mine wastes have generated without any proper treatment and dispersed downslope into the Hengshi River, which is mainly employed to irrigate agricultural land for vegetables and crops (Zhuang et al., 2009). Past investigations have demonstrated that about 83 villages, $585 \times 10^{4} \mathrm{~m}^{2}$ paddy fields, and $21 \times 10^{4} \mathrm{~m}^{2}$ ponds were polluted owing to mining activities around the mine (Zhou et al., 2004). Until 2006, water diversion irrigation realized in Mt. Dabao mine, yet cumulative effects of heavy metals pollution and environmental ecological impact will last for a considerable time (Chen, 2012). In recent years, the researchers mostly concentrated on research polluted characteristics of soil (Zhou et al., 2007), water (Chen et al., 2007), plant (Zhuang et al., 2009, 2013), distribution (Liao et al., 2016; Li et al., 2009) and migration (Chen et al., 2015, 2018; Wang et al., 2019) of heavy metals, assessment of soil heavy metals contamination (Zhao et al., 2012; Shu et al., 2018) etc., few information is available either on nematodes structure or soil microbial mass of the mine sites.

Soil microbial biomass is the source and library of nutrients available for plant growth (Thakura et al., 2019), drives substance conversion and nutrient circulation in soil, and represents active parts of soil nutrients, including soil biomass carbon and nitrogen (Singh et al., 2018). Nematodes, the most abundant and ubiquitous multicellular organisms in soil, which distributed widely, identified easily with sample structure, and play a critical role in soil functioning. Nematodes can regulates bacterial and fungal populations, impact the decomposition of organic matter and influence nitrogen-carbon cycle in soil (Chen et al., 1999; Ingham et al., 1985; Savin et al., 2001). Soil microbial biomass and nematode communities, the center among soil-based biological communities, a sensor to disturbance of soil ecosystem, are sensitive to environmental changes, and using its change trend to evaluate soil quality and pollution has been a hot spot in international researches in the field of different soil ecosystem, e.g. farmland, forest, grassland, wetland, etc. (Yang et al., 2018; Wu et al., 2019; Cerevková et al., 2020). Nevertheless, the change of soil microbial biomass and nematode communities are poorly understood in agricultural field ecosystem which was irrigated with sewage for more than 20 years in polymetallic mining areas.

Our objectives were to (a) determine the extent of pollution, comprehensively that of $\mathrm{Cu}, \mathrm{Zn}, \mathrm{Pb}$, and As (Wang et al., 2016) caused by sewage irrigation owing to polymetallic mining; (b) assess the long-term influences of metals pollution on the soil microbial and nematode communities; (c) infer the relationship among soil microbial biomass, nematode parameters and soil physicochemical factors following sewage irrigating. 


\section{Materials and methods}

\section{Study sites and soil sampling}

The area of Mt. Dabao mine $\left(113^{\circ} 40^{\prime} \sim 113^{\circ} 43^{\prime} \mathrm{E}, 24^{\circ} 30^{\prime} \sim 24^{\circ} 36^{\prime} \mathrm{N}\right)$ is situated in the northern part of Guangdong, southern China. The region has a subtropical monsoon climate with an average annual temperature of $20.3{ }^{\circ} \mathrm{C}$ and precipitation of $1782.7 \mathrm{~mm}$. Our sampling area is on both side of Hengshui River and predominantly covered with paddy (Fig. 1). Parts of the selected area have been subjected to sewage irrigation owing to polymetallic mining and processing upstream, while other areas irrigated with unpolluted water were uninfluenced and regarded as non-polluted control. The soils at study area are waterloggogenic paddy in gray brown, distributed fairly evenly throughout all sewage area and basically within sandy sticky clay loam to clay loam (Fig. 2).

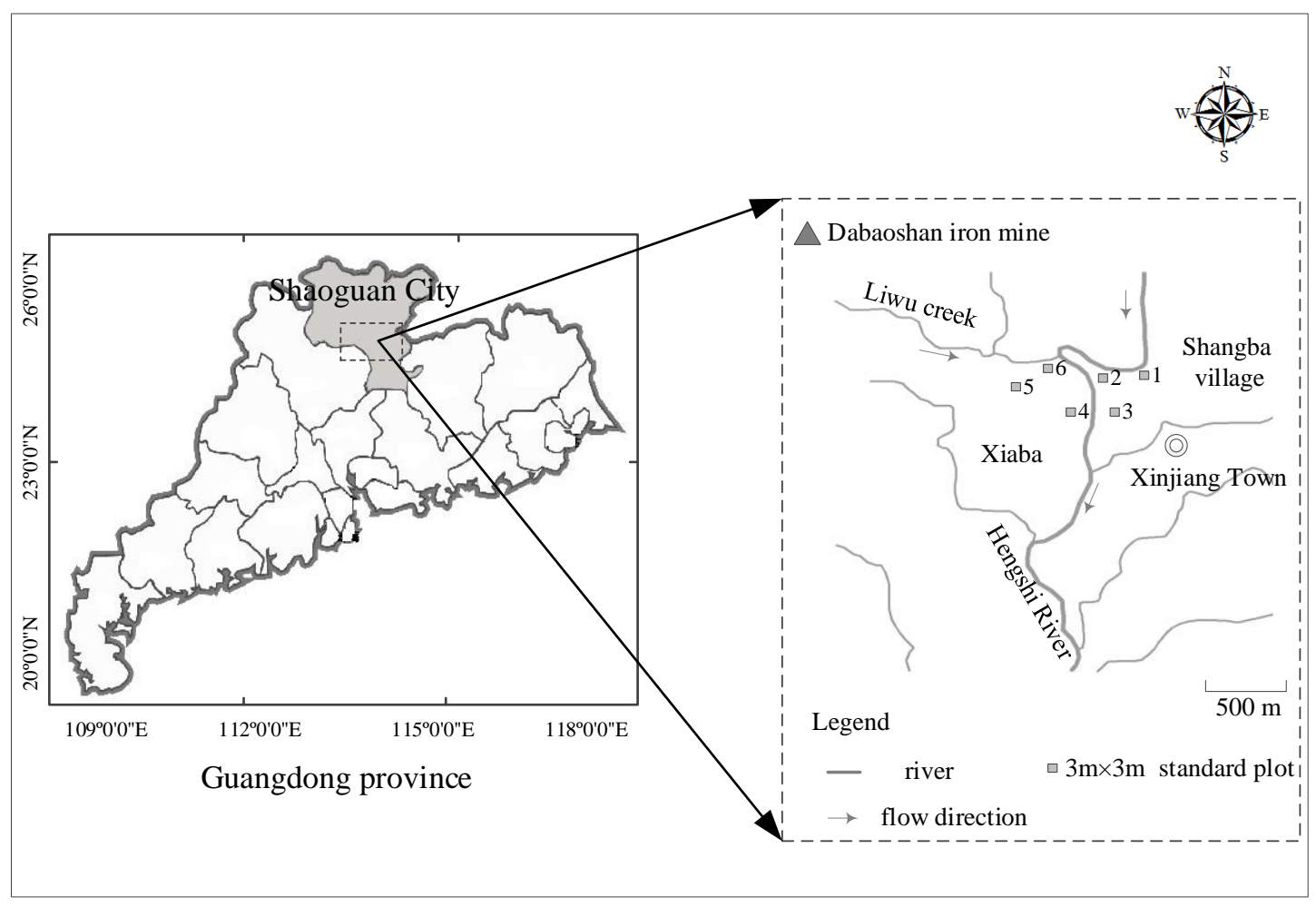

Figure 1. Map of research plots at Dabaoshan polymetallic mine area

Soil samplings were taken in March, 2006. The study area was divided into 6 sampling areas-S1, S2, S3, S4, S5 and S6 (Table 1). 6 soil samplings, each consist of 3 composite sampling, were randomly collected in excess of $10 \mathrm{~m}$ interdistance from each area. S4, S5 and S6 were situated in right of Hengshui River near Xiaba Village, which were irrigated with wastewater discharge from Mt. Dabao mining activities upstream, thus we a priori referred to them as 'sewage irrigation' area (SIA) as opposed to the 'non-sewage irrigation' area (NSIA), S1, S2 and S3. 6 composite samples each consist of $1000 \mathrm{~g}$ (a composite of 3 samples combined), were obtained from the upper $10 \mathrm{~cm}$ using a wooden shovel. Soil samples were put into ziplocked plastic bags and sealed tightly in a preservation box until laboratory processing. From each soil samples, $500 \mathrm{~g}$ 
were stored in $4{ }^{\circ} \mathrm{C}$ and used to the measurement of soil microbial biomass and nematode communities, another were used for nutrients, soil characteristics and heavy metal analyses.

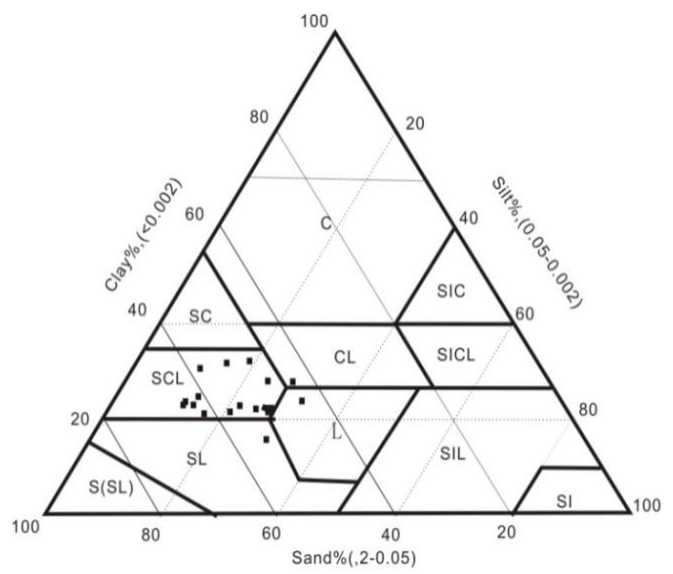

$\begin{array}{clll}\text { Note: } & & & \\ \text { S : } & \text { Sandy soil } & \text { SCL : } & \text { Sandy clay loam } \\ \text { LS : } & \text { Loamy sand } & \text { CL : } & \text { Clay loam } \\ \text { SL : } & \text { Sandy loam } & \text { SICL : } & \text { Silty clay loam } \\ \text { SI : } & \text { Silty soil } & \text { SC : } & \text { Sandy clay } \\ \text { L : } & \text { Loam } & \text { SIC : } & \text { Silty clay } \\ \text { SIL : } & \text { Silty loam } & \text { C : } & \text { Clay }\end{array}$

- Soil textures at various sampling points

Figure 2. Triangle diagram of soil texture distribution at sampling points of Dabaoshan polymetallic mine area

\section{Soil properties}

Soil $\mathrm{pH}$ of the subsamples was measured in the soil suspension of a 1:2.5 soil: water mixture by PHS-25 (ISRIC, 1995). Soil water content (S.W.C) of the subsamples was detected gravimetrically as percentage of dry mass by drying the samples to a constant weight at $105^{\circ} \mathrm{C}$. Soil organic matter (S.O.M) of the subsamples was measured by the Walkley-Black's procedure (Nelson et al., 1982). Soil content of total N was obtained by the Kjeldahl method (Bremner et al., 1982) Soil content of available $\mathrm{Cu}$ and $\mathrm{Zn}$ were analyzed using an atomic adsorption spectrophotometer (AAS, jena vario). Soil content of $\mathrm{Cu}, \mathrm{Zn}$ were determined using a flame atomic adsorption spectrophotometer (AAS, jena vario 6). Soil content of $\mathrm{Pb}$ was measured using graphite furnace atomic absorption spectrophotometer (GFAAs, Jena ZEENIT 60). Soil content of As was detected using a spectrophotometer (AFS-8230).

\section{Soil microbial}

Soil microbial biomass was analyzed using a chloroform fumigation- $\mathrm{K}_{2} \mathrm{SO}_{4}$ extraction method. 50-g fresh soil subsamples were adjusted to $40 \%$ water-holding capacity and fumigated in a $\mathrm{CHCl}_{3}$-saturated atmosphere in a desiccator for $24 \mathrm{~h}$ at $25^{\circ} \mathrm{C}$ in the dark, $\mathrm{CO}_{2}$ released from cells lyse of soil microbial death was absorbed by sodium hydroxide solution. Then, the fumigated and corresponding nonfumigated (control) subsamples were transferred to 0.2-L glass jars and add $0.1 \mathrm{~L} \mathrm{~K}_{2} \mathrm{SO}_{4}$ $\left(0.5 \mathrm{~mol} \cdot \mathrm{L}^{-1}\right)$, keep the soil suspension of a 1:4 soil:water mixture, vibrating $\left(300 \mathrm{r} \cdot \mathrm{min}^{-}\right.$ ${ }^{1}$ ) at $25^{\circ} \mathrm{C}$ for $30 \mathrm{~min}$, filtrated and measured immediately or stored at $-18{ }^{\circ} \mathrm{C}$.

Soil microbial biomass $\left(\mathrm{C}_{\mathrm{mic}}\right)$ was measured by Carbon- automatic analysis (Phoenix 8000) and $\mathrm{C}_{\mathrm{mic}}$ was calculated as

$$
\mathrm{C}_{\text {mic }}=\left[\left(\mathrm{CO}_{2}-\mathrm{C} \text { from fumigated soil }\right)-\left(\mathrm{CO}_{2}-\mathrm{C} \text { from control sample }\right)\right] / k c \text { (Eq.1) }
$$


Extract sample nitrified with $0.2 \mathrm{ml} \mathrm{CuSO} 4\left(0.19 \mathrm{~mol} \cdot \mathrm{L}^{-1}\right)$ and $5 \mathrm{ml} \mathrm{H}_{2} \mathrm{SO}_{4}$, then using Flow injection nitrogen analyzer (FIAStar 500) to determined soil microbial biomass $\left(\mathrm{N}_{\mathrm{mic}}\right)$, and $\mathrm{N}_{\mathrm{mic}}$ was calculated as

$$
\mathrm{N}_{\text {mic }}=\left[\left(\mathrm{NH}_{4}{ }^{+}-\mathrm{N} \text { from fumigated soil }\right)-\left(\mathrm{NH}_{4}{ }^{+}-\mathrm{N} \text { from control sample }\right)\right] / k c \quad \text { (Eq.2) }
$$

by using kc of 0.45 (Zang et al.; 2015).

Soil microbial $\mathrm{C} / \mathrm{N}$ ratio can be used as indicator to evaluate the capability and effectiveness of nitrogen supply in soil (Xiao et al., 2003), and calculated as

$$
\mathrm{C} / \mathrm{N}=\mathrm{C}_{\text {mic }} / \mathrm{N}_{\text {mic }}
$$

The change of microbial quotient reflects the conversion efficiency of organic substances input into the soil to microbial biomass carbon, the greater it is, the faster the soil organic carbon circulates (Gao et al., 2015), and $\mathrm{Q}_{\text {mic }}$ calculated as

$$
\mathrm{Q}_{\mathrm{mic}}=\mathrm{C}_{\mathrm{mic}} / \mathrm{T}_{\text {S.O.C }}
$$

The conversion coefficient SOM and TS.O.C was 1.724 (Qiu et al., 2015).

\section{Nematodes}

In ecological studies, soil nematodes are usually divided into 5 trophic groups, usually Bacterivores (BF), Fungivores (FF), Plant-parasites (PP), Omnivores and Predators are considered as the mayor trophic habits (Chen et al., 2003; Hodda et al., 1994; Porazinska et al., 1999; Nagy et al., 2004; Weiss et al., 1991). The nematode community was analyzed by absolute abundance of individuals $100 \mathrm{~g}^{-1}$ dry soil.

\section{Statistical analysis}

The data presented in this work are reported as oven-dried weight. All data in this work were subjected to statistical analysis of variance using the SPSS procedure (version 18.0, IBM). The sampling data measured for normality using a Kruskal Wallis test (version 12, Statistica). Significant differences among soil samples were identified by one way analysis of variance (ANOVA) to detect the differences in soil concentration of heavy metals, soil conmicrobial biomass and soil nematodes assemblages among SIA and NSIA followed by Least Significant Difference (LSD) tests $(P<0.05)$, the relations between soil microbial biomass $\mathrm{C} \& \mathrm{~N}$ and soil nematode community structure versus soil environmental factors were inferred by Spearman correlation.

\section{Results}

Effects of 20 years' sewage irrigation on soil physical and chemical properties and heavy metal concentration in paddy fields

There is a significant difference in soil $\mathrm{pH}$ between NSIA and SIA, and the soil of both areas is basically acidic, while the $\mathrm{pH}$ value of SIA is lower than that of NSIA (Table 1). In the case of permanent framing, sewage irrigation has no significant effect on soil organic matter, total nitrogen and soil water content. There are significant differences in available $\mathrm{Cu}$ and $\mathrm{Zn}$, and the total $\mathrm{Cu}, \mathrm{Zn}, \mathrm{Pb}$ and As contents in the 
$0 \sim 10 \mathrm{~cm}$ deep soil of paddy fields between SIA and NSIA. The concentration of heavy metals ranged between 2.93-67.17 mg/kg for available $\mathrm{Cu}, 1.66-22.00 \mathrm{mg} / \mathrm{kg}$ for available $\mathrm{Zn}, 21.27-280.67 \mathrm{mg} / \mathrm{kg}$ for $\mathrm{Cu}, 68.47-315.00 \mathrm{mg} / \mathrm{kg}$ for $\mathrm{Zn}, 41.20-$ $212.67 \mathrm{mg} / \mathrm{kg}$ for $\mathrm{Pb}, 14.67-74.10 \mathrm{mg} / \mathrm{kg}$ for As. The available $\mathrm{Cu}$ and $\mathrm{Zn}$, and the total $\mathrm{Cu}, \mathrm{Zn}, \mathrm{Pb}$ and $\mathrm{As}$ contents in paddy fields of SIA are higher than those in paddy fields of NSIA by 13.60, 7.69, 8.56, 2.35, 2.96 and 3.11 times on average. Soil in the SIA is stronger in acidity and suffers higher pollution overall.

Table 1. Statistical summary of the general descriptive parameters and heavy metal contents. Mean values for SIA and NSIA

\begin{tabular}{c|c|c|c|c|c|c}
\hline \multirow{2}{*}{ Soil properties } & \multicolumn{2}{|c|}{ NSIA } & \multicolumn{3}{c}{ SIA } \\
\cline { 2 - 6 } & S1 & S2 & S3 & S4 & S5 & S6 \\
\hline Basic soil properties & & & & \\
pH & $5.73 \pm 0.12 \mathrm{a}$ & $5.42 \pm 0.39 \mathrm{~b}$ & $5.65 \pm 0.20 \mathrm{a}$ & $5.71 \pm 0.24 \mathrm{a}$ & $4.63 \pm 0.30 \mathrm{c}$ & $4.75 \pm 0.36 \mathrm{c}$ \\
S.W.C $(\%)$ & $0.17 \pm 0.00 \mathrm{a}$ & $0.20 \pm 0.01 \mathrm{a}$ & $0.29 \pm 0.02 \mathrm{a}$ & $0.34 \pm 0.12 \mathrm{a}$ & $0.28 \pm 0.08 \mathrm{a}$ & $0.30 \pm 0.04 \mathrm{a}$ \\
S.O.M $(\mathrm{g} / \mathrm{kg})$ & $22.3 \pm 1.14 \mathrm{c}$ & $19.7 \pm 2.43 \mathrm{~d}$ & $28.6 \pm 0.39 \mathrm{a}$ & $25.8 \pm 0.38 \mathrm{~b}$ & $27.0 \pm 1.81 \mathrm{ab}$ & $21.5 \pm 3.11 \mathrm{c}$ \\
$\mathrm{N}(\mathrm{g} / \mathrm{kg})$ & $1.22 \pm 0.01 \mathrm{a}$ & $1.23 \pm 0.10 \mathrm{a}$ & $1.61 \pm 0.10 \mathrm{a}$ & $1.50 \pm 0.42 \mathrm{a}$ & $1.44 \pm 0.50 \mathrm{a}$ & $1.23 \pm 0.13 \mathrm{a}$ \\
Available Cu $(\mathrm{mg} / \mathrm{kg})$ & $3.06 \pm 0.19 \mathrm{e}$ & $2.93 \pm 0.31 \mathrm{e}$ & $5.59 \pm 0.40 \mathrm{~d}$ & $41.23 \pm 21.34 \mathrm{c}$ & $49.17 \pm 12.43 \mathrm{~b}$ & $67.17 \pm 14.67 \mathrm{a}$ \\
Available Zn $(\mathrm{mg} / \mathrm{kg})$ & $2.66 \pm 0.32 \mathrm{e}$ & $1.66 \pm 0.14 \mathrm{f}$ & $2.97 \pm 0.18 \mathrm{~d}$ & $12.80 \pm 8.50 \mathrm{c}$ & $21.26 \pm 21.17 \mathrm{~b}$ & $22.00 \pm 7.79 \mathrm{a}$ \\
\hline Heavy metals $(\mathrm{mg} / \mathrm{kg})$ & & & & & \\
$\mathrm{Cu}$ & $21.27 \pm 2.14 \mathrm{f}$ & $23.07 \pm 1.86 \mathrm{e}$ & $34.33 \pm 2.87 \mathrm{~d}$ & $173.33 \pm 56.37 \mathrm{c}$ & $219.00 \pm 33.06 \mathrm{~b}$ & $280.67 \pm 23.35 \mathrm{a}$ \\
$\mathrm{Zn}$ & $139.23 \pm 68.21 \mathrm{~d}$ & $68.47 \pm 10.11 \mathrm{f}$ & $119.00 \pm 1.00 \mathrm{e}$ & $206.67 \pm 61.58 \mathrm{c}$ & $247.00 \pm 85.16 \mathrm{~b}$ & $315.00 \pm 19.16 \mathrm{a}$ \\
$\mathrm{Pb}$ & $61.67 \pm 8.36 \mathrm{~d}$ & $41.20 \pm 16.18 \mathrm{f}$ & $47.87 \pm 6.51 \mathrm{e}$ & $107.27 \pm 25.54 \mathrm{c}$ & $126.67 \pm 21.03 \mathrm{~b}$ & $212.67 \pm 22.48 \mathrm{a}$ \\
$\mathrm{As}$ & $14.67 \pm 0.64 \mathrm{f}$ & $16.77 \pm 3.10 \mathrm{~d}$ & $15.47 \pm 2.30 \mathrm{e}$ & $20.53 \pm 5.15 \mathrm{c}$ & $51.23 \pm 16.55 \mathrm{~b}$ & $74.10 \pm 17.96 \mathrm{a}$ \\
\hline
\end{tabular}

Total soil sampling 18. Mean \pm standard deviation, S.W.C soil water content, S.O.M soil organic matter, (a, b and c). Significant difference $(p<0.01)$ between 6 sampling sites

\section{Effect of 20 years' sewage irrigation on soil biomass $C$ and $N$ in paddy fields}

In the NSIA and SIA, from Equation 1, the soil microbial biomass $\mathrm{C}$ content ranges in $740.3 \sim 1,600.3 \mathrm{mg} / \mathrm{kg}$ and $705.8 \sim 1093.3 \mathrm{mg} / \mathrm{kg}$ with a mean of $1,154.3 \mathrm{mg} / \mathrm{kg}$ and $856.9 \mathrm{mg} / \mathrm{kg}$ respectively; from Equation 2, the soil microbial biomass $\mathrm{N}$ content ranges in $92.04 \sim 217.63 \mathrm{mg} / \mathrm{kg}$ and $141.83 \sim 167.14 \mathrm{mg} / \mathrm{kg}$ with a mean of $174.28 \mathrm{mg} / \mathrm{kg}$ and $154.93 \mathrm{mg} / \mathrm{kg}$ respectively, and both the means and mathematical statistics suggest that there is a significant difference between heavy metals effects on soil microbial biomass $\mathrm{C}$ and $\mathrm{N}$ of paddy fields. From Equation 3, in the NSIA and SIA, the soil microbial biomass $\mathrm{C} / \mathrm{N}$ ratio ranges in $0.34 \sim 1.74$ and $0.42 \sim 0.77$ with a mean of 0.87 and 0.56 , respectively. From Equation 4, the soil microbial quotient ranges in 5.72 9.82 and 5.16 6.98 with a mean of 8.40 and 5.93, respectively (Fig. 3).

\section{Effect of 20 years' sewage irrigation on different groups of soil nematode in paddy fields}

There are significant differences in quantity of various soil nematodes between the SIA and NSIA (Fig. 4), the NSIA is 2.73 times of the SIA in quantity of soil nematodes, and the density of soil nematodes in both areas follows the rule below: bacterivores $>$ plant parasites $>$ predators $>$ omnivores. The density of bacterivores, plant-parasites and fungivores in the NSIA are clearly higher than that in the SIA by $2.44,0.80$ and 4.48 times respectively, but the quantity of omnivores and predators was not so different and that of fungivores changes greatly. 


$$
\text { - } 4921 \text { - }
$$
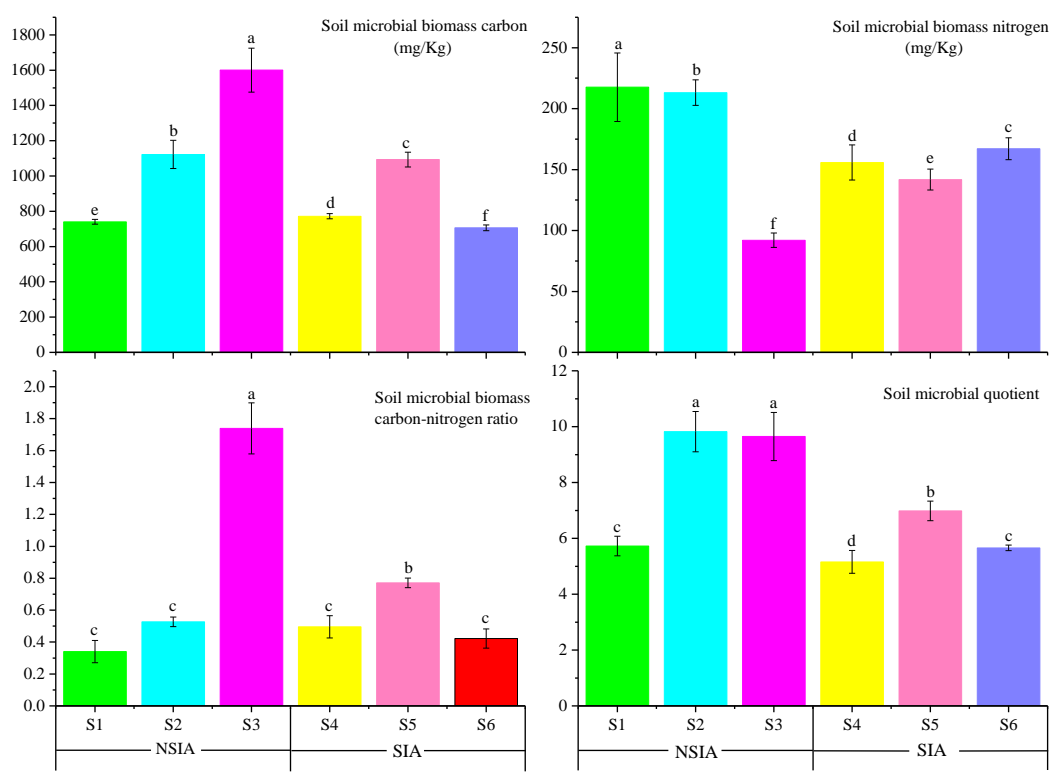

Figure 3. Characteristics of soil microbial biomass $C$ and $N$, soil microbial $C / N$ ratio, microbial quotient in SIA and NSIA. (Different lower-case letters refer to the level of significance 5\% that the difference between standard samples reaches)

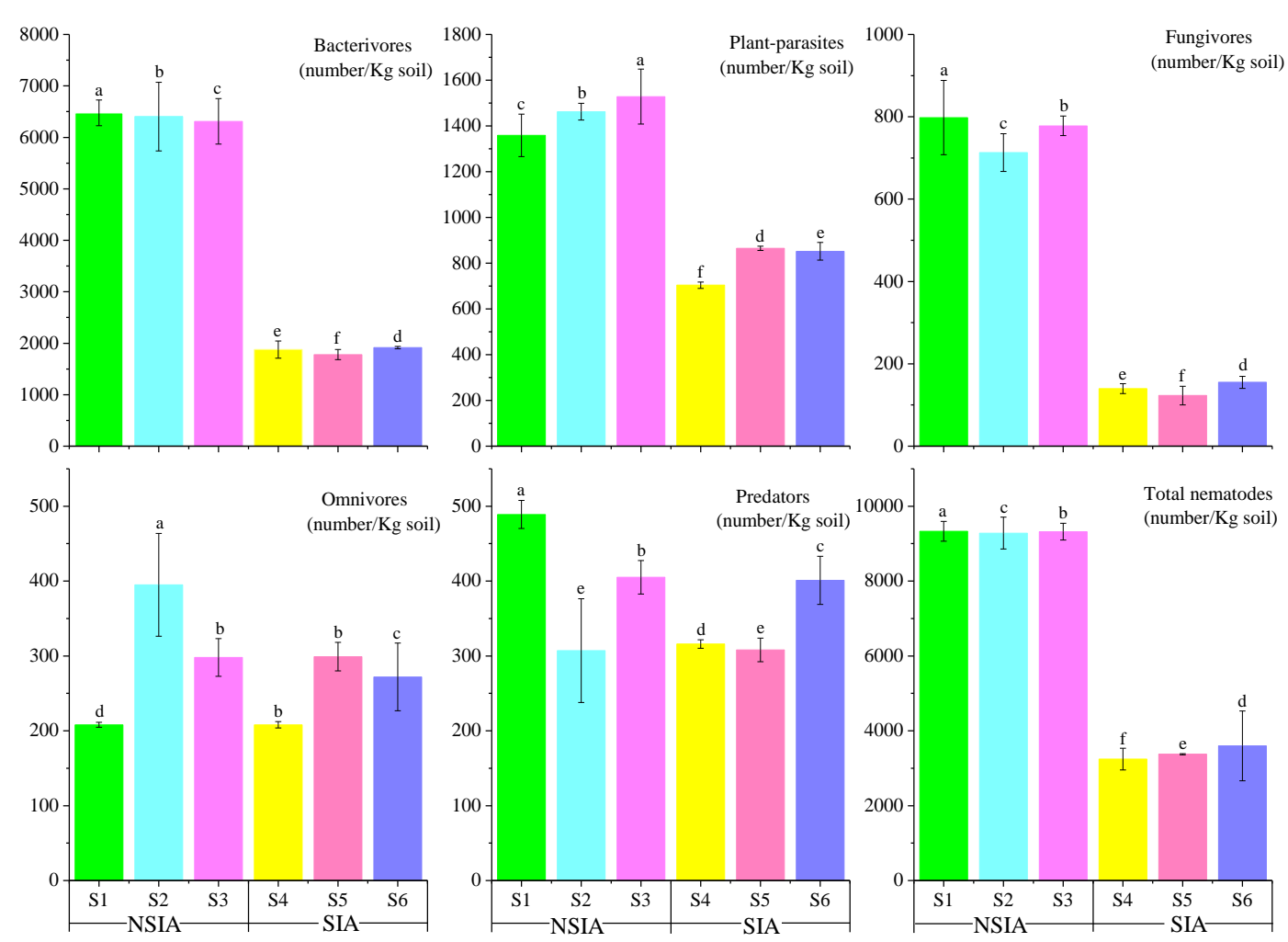

Figure 4. Characteristics of each type of nematodes in SIA and NSIA. (Note: Different lowercase letters refer to the level of significance 5\% that the difference between standard samples reaches) 


\section{Correlation analysis of soil microbial biomass $C \& N$ and nematode group structure versus soil environmental factors}

Soil microbial biomass $\mathrm{C}$ has significant positive correlation with organics and significant negative correlation with available $\mathrm{Cu}$, and the total $\mathrm{Zn}, \mathrm{Pb}$ contents; soil microbial biomass $\mathrm{N}$ has significant positive correlation with organics; bacterivores, fungivores and the total quantity of nematodes have extremely significant positive correlation with $\mathrm{pH}$ and extremely significant negative correlation with available $\mathrm{Cu}$ and $\mathrm{Zn}$, and the total $\mathrm{Cu}, \mathrm{Zn}, \mathrm{Pb}$ and As contents; plant parasites has significant positive correlation with $\mathrm{pH}$ and extremely significant negative correlation with available $\mathrm{Cu}$ and $\mathrm{Zn}$, and the total $\mathrm{Cu}, \mathrm{Zn}, \mathrm{Pb}$ and As contents (Table 2).

Table 2. Correlation of soil microbial biomass $C \& N$ and soil nematode community structure versus soil environmental factors

\begin{tabular}{c|c|c|c|c|c|c|c|c|c|c}
\hline & $\mathbf{p H}$ & Organics & $\begin{array}{c}\text { Total } \\
\text { nitrogen }\end{array}$ & $\begin{array}{c}\text { Water } \\
\text { content }\end{array}$ & $\begin{array}{c}\text { Available } \\
\mathbf{C u}\end{array}$ & $\begin{array}{c}\text { Available } \\
\mathbf{Z n}\end{array}$ & $\mathbf{C u}$ & $\mathbf{Z n}$ & $\mathbf{P b}$ & As \\
\hline $\begin{array}{c}\text { Soil microbial } \\
\text { biomass C }\end{array}$ & 0.137 & $0.530^{*}$ & 0.121 & 0.033 & $-0.471^{*}$ & -0.397 & -0.450 & $-0.509^{*}$ & $-0.545^{*}$ & -0.358 \\
\hline $\begin{array}{c}\text { Soil microbial } \\
\text { biomass N }\end{array}$ & 0.114 & $0.647^{*}$ & 0.126 & 0.177 & -0.215 & -0.240 & -0.226 & -0.214 & -0.098 & -0.118 \\
\hline Bacterivores & $0.622^{* *}$ & -0.208 & -0.024 & -0.435 & $-0.951^{* *}$ & $-0.940^{* *}$ & $-0.952^{* *}$ & $-0.885^{* *}$ & $-0.824^{* *}$ & $-0.725^{* *}$ \\
\hline Plant parasites & $0.475^{*}$ & -0.131 & -0.012 & -0.397 & $-0.894^{* *}$ & $-0.863^{* *}$ & $-0.889^{* *}$ & $-0.839^{* *}$ & $-0.773^{* *}$ & $-0.615^{* *}$ \\
\hline Fungivores & $0.634^{* *}$ & -0.164 & -0.018 & -0.425 & $-0.943^{* *}$ & $-0.932^{* *}$ & $-0.944^{* *}$ & $-0.858^{* *}$ & $-0.809^{* *}$ & $-0.719^{* *}$ \\
\hline Omnivores & -0.276 & -0.272 & -0.032 & -0.144 & -0.241 & -0.194 & -0.222 & -0.401 & -0.258 & 0.006 \\
\hline Predators & 0.312 & -0.099 & -0.045 & -0.251 & -0.290 & -0.308 & -0.304 & -0.041 & -0.052 & -0.104 \\
\hline $\begin{array}{c}\text { Total quantity } \\
\text { of nematodes }\end{array}$ & $0.599^{* *}$ & -0.200 & -0.023 & -0.433 & $-0.942^{* *}$ & $-0.928^{* *}$ & $-0.942^{* *}$ & $-0.874^{* *}$ & $-0.812^{* *}$ & $-0.704^{* *}$ \\
\hline
\end{tabular}

$*$ and $* *$ means the significance at the level of $5 \%$ and $1 \%$ respectively, $\mathrm{n}=18$

\section{Discussion}

(1) Heavy metals that are resistant to degradation and difficult to migrate accumulate continually in soil and become permanent pollutants, not only change soil's physical and chemical properties, affecting crops growth, but also enter human bodies via the food chain and endanger human health and life (Huang et al., 2018). The result of the research indicates that, after 20 years' irrigation with mine sewage, the mean content of soil microbial biomass $\mathrm{C}$ in paddy fields of the SIA drops by $25.76 \%$ compared with the NSIA, and the mean content of soil microbial biomass $\mathrm{N}$ drops by $11.10 \%$. These manifest that composite heavy metals of high contents have significantly affected soil microbial biomass $\mathrm{C}$ and $\mathrm{N}$, because soil microbes in paddy fields of the mine area has long suffered intimidation of heavy metals, and composite heavy metals of high contents have led to changed size of soil microbial groups by destroying protein structure and functions as well as the integrity of cytomembranes, etc., thus affecting the form, growth, and development, and metabolism of microbes in soil (Leita et al., 1995). The results from researches of Jiang et al. (2010) and Wang et al. (2003) on microbe communities in soil polluted by composite heavy metals also proved this. The reduction of microbial quotient due to the concentration of heavy metals indicates that the content of heavy metals in high concentration limits the circulation rate of organic carbon in soil, which may be correlated with the intimidation on microbial biomass imposed by heavy metals. Results from many researches demonstrate that as the concentration of heavy metals rise, the quantity of fungus with higher resistance in soil 
increases, thus rendering the increase (Khan et al., 1998) of microbial biomass $\mathrm{C} / \mathrm{N}$ ratio. Results from some researches prove, however, the decrease (Wang et al., 2003) of microbial biomass $\mathrm{C} / \mathrm{N}$ ratio with increasing content of heavy metals. The result from this experiment is consistent with the research result of the latter, i.e. the effect of heavy metals in high concentration decreases soil microbial biomass $\mathrm{C} / \mathrm{N}$ ratio (44\%), which may be attributable to farming habits or multiple actions of composite heavy metals changed some functional groups of soil microbial communities and community structure.

(2) Soil nematodes are small secondary biological groups leeching on to soil environments and its communities are more vulnerable to effect of soil's physical and chemical properties. The sewage in the mine area contain available $\mathrm{Cu}$ and $\mathrm{Zn}$, and the total $\mathrm{Cu}, \mathrm{Zn}, \mathrm{Pb}$ and $\mathrm{As}$ with high concentration, all of which enter soil directly in various areas in running water, affecting structure of nematode communities in soil. The result from this research indicates that bacterivores, plant parasites, fungivores, omnivores and predators in soil of the SIA are $244.29 \%, 79.64 \%, 447.61 \%, 15.66 \%$ and $17.17 \%$ lower than those in the NSIA respectively; and in both the SIA and NSIA, bacterivores are the most in quantity and fungivores vary the most in quantity possibly because a vast majority of organisms in soil is bacteria and therefore bacterivores are dominant in various trophic types regardless of SIA or NSIA; omnivores and predators are most sensitive to the environment (Popovici, 1992), the result of this experiment indicate that these two nematodes were least affected, when soil is polluted by heavy metals, under the action of external pressure, the species diversity in the ecosystem diminishes while the dominance of few species rises, according to the "Pressure Hypothesis" advanced by Odum, a renowned ecologist in USA (Pennanen et al., 1996). Therefore, within a certain range of concentration, heavy metals in soil would stimulate the growth of soil nematodes to some degree; in the area surveyed in the experiment, it mainly contributes to growth of some kinds of omnivores and predators in soil.

(3) Results from correlation analysis demonstrate that soil microbial biomass $\mathrm{C}$ and $\mathrm{N}$ have significant positive correlation with organics, consistent with previous conclusions (Bruggen et al., 2000; Yu et al., 2003), indicating microbial biomass $\mathrm{C}$ and $\mathrm{N}$ can represent soil's fertility; the significant negative correlation of soil microbial biomass $\mathrm{C}$ with available $\mathrm{Cu}, \mathrm{Zn}$ and $\mathrm{Pb}$ proves that the available $\mathrm{Cu}, \mathrm{Zn}$ and $\mathrm{Pb}$ in heavy metals with high concentration interfere with soil organism activity, the result from the research of Kao et al. (2006) indicates the addition of heavy metals into soil will reduce considerably soil biomass $\mathrm{C}$ and $\mathrm{N}$, and Guo et al. (2018) gets the same conclusion from the research on effect of addition of exogenous $\mathrm{Cd}$ on soil microbes in red-soil paddy fields. Soil nematodes are closely tied to soil's physical and chemical properties which can lead to change in quantity and diversity of nematodes, and of which $\mathrm{pH}, \mathrm{Zn}, \mathrm{Cr}, \mathrm{Cu}$ and $\mathrm{Pb}$ have considerable effect on soil nematodes (Liu et al., 2012). The results from research indicate, $\mathrm{pH}$ has a significant/extremely significant positive correlation with plant parasites, bacterivores, fungivores, total quantity of nematodes, revealing soil $\mathrm{pH}$ affects significantly the quantities of nematodes of all nutrient types, and the quantity of soil nematodes is affected by both the total content and the effective form of heavy metals in soil (Yang et al., 2019). Bacterivores, plant parasites, fungivores and total quantity of nematodes have extremely significant negative correlation with available $\mathrm{Cu}$ and $\mathrm{Zn}$, and the total $\mathrm{Cu}, \mathrm{Zn}, \mathrm{Pb}$ and $\mathrm{As}$ content, which is consistent with the conclusion from researches of Weiss et al. (1991), but totally different with those from researches of Park et al. (2011), Wang et al. (2012) and 
Li et al. (2006), possibly because the difference in spatial distribution and soil parent materials of soil for sampling.

\section{Conclusion}

Overall, with backward technology, the content of available $\mathrm{Cu}$ and $\mathrm{Zn}$, and the total $\mathrm{Cu}, \mathrm{Zn}, \mathrm{Pb}$ and $\mathrm{As}$ content in Hengshi River increased sharply owing to long-running polymetallic mining activities. Mine sewage irrigation reduced soil microbial biomass $\mathrm{C}$ and $\mathrm{N}$, bacterivores, plant parasites, fungivores, and with no obvious effect on omnivores and predators. The significantly positive correlations between soil microbial biomass $\mathrm{C}$ and $\mathrm{N}$ with organics indicate that Organic matter is an important source of nutrients for microorganisms. Soil microbial biomass $\mathrm{C}$ and $\mathrm{N}$, bacterivores, plantparasites, fungivores and the total quantity of nematodes has a significant negative correlation with the content of available $\mathrm{Cu}$ and $\mathrm{Zn}$, and the total $\mathrm{Cu}, \mathrm{Zn}, \mathrm{Pb}$ and $\mathrm{As}$ content, which suggesting that Heavy metal stimulated microbial biomass and nematode biomass consumption.

Our study indicates that mine sewage irrigation led to a decline in soil quality in the diggings. Hence, protection of biodiversity from safe irrigation is urgently needed in farmland ecosystems, as any heavy metals affecting the survival of microorganisms and nematodes will affect the recovery of farmland ecosystems, and more related research should be done in the future.

Acknowledgements. This work was supported by the Natural Science Foundation of Guangdong Province (06025926). Special thanks to teachers FU and ZHOU from South China Botanical Garden, Chinese Academy of Sciences for their guidance and analysis of the nematode experiment.

\section{REFERENCES}

[1] Bremner, J. M., Mulvaney, C. S. (1982): Nitrogen: Total Content. - In: Page, A. L., Miller, R. H., Keeney, D. R. (eds.) Methods of Soil Analysis, Part 2. 2nd Ed. Agron. Monogr. 9. Agronomy Society of America and Soil Science Society of America, Madison, WI, pp. 595-624.

[2] Bruggen, A. H. C. V., Semenov, A. M. (2000): In search of biological indicators for soil health and disease suppression. - Applied Soil Ecology 15(1): 0-24.

[3] Čerevková, A., Ivashchenko, K., Miklisová, D., et al. (2020): Influence of invasion by Sosnowsky's hogweed on nematode communities and microbial activity in forest and grassland ecosystems. - Global Ecology and Conservation 21: e00851.

[4] Chen, A., Lin, C., Lu, W., et al. (2007): Well water contaminated by acidic mine water from the Dabaoshan mine, South China: chemistry and toxicity. - Chemosphere 70(2): 248-255.

[5] Chen, J., Ferris, H. (1999): The effect of nematode grazing on nitrogen mineralization during fungal decomposition of organic matter. - Soil Biology and Biochemistry 31: 1265-1279.

[6] Chen, L., Li, Q., Liang, W. (2003): Effect of agrochemicals on nematode community structure in a soybean field. - Bull. Environ. Contam. Toxicol. 71: 755-760.

[7] Chen, M. Q., Lu, G. N., Guo, C. L., et al. (2015): Sulfate migration in a river affected by acid mine drainage from the Dabaoshan mining area, South China. - Chemosphere 119: 734-743. 
[8] Chen, M. Q., Lu, G. N., Wu, J. X., et al. (2018): Migration and fate of metallic elements in a waste mud impoundment and affected river downstream: a case study in Dabaoshan mine, South China. - Ecotoxicology and Environmental Safety 164: 474-483.

[9] Chen, S. X. (2012): Soil and Water Loss Characteristics and Heavy Metal Tolerant Plants Selection of Dabaoshan Mine of Guangdong. - Nanjing Forestry University, Nanjing (in Chinese).

[10] Cortes-Maramba, N., Reyes, J. P., Francisco-Rivera, A. T., et al. (2006): Health and environmental assessment of mercury exposure in a gold mining community in Western Mindanao, Philippines. - Journal of Environmental Management 81: 126-134.

[11] Gao, S. J., Cao, W. D., Bai, J. S., et al. (2015): Long-term application of winter green manures changed the soil microbial biomass properties in red paddy soil. - Acta Pedologica Sinica 52(04): 902-910 (in Chinese).

[12] Getaneh, W., Alemayehu, T. (2006): Metal contamination of the environment by placer and primary gold mining in the Adola region of Southern Ethiopia. - Environmental Geology 50: 339-352.

[13] Guo, B. L., Chen, X. M., Jing, F., et al. (2018): Effects of exogenous cadmium on microbial biomass and enzyme activity in red paddy soil. - Journal of Agro-Environment Science 37(09): 1850-1855 (in Chinese).

[14] Heikens, A., Peijnenburg, W. J. G. M., Hendriks, A. J. (2001): Bioaccumulation of heavy metals in terrestrial invertebrates. - Environmental Pollution 113: 385-393.

[15] Hodda, M., Wanless, F. R. (1994): Nematodes from an English chalk grassland, population ecology. - Pedobiologia 38: 530-545.

[16] Huang, Y., Chen, Q. Q., Deng, M. H., et al. (2018): Heavy metal pollution and health risk assessment of agricultural soils in a typical peri-urban area in Southeast China. - Journal of Environmental Management 207: 159-168.

[17] Ingham, R. E., Trofymov, J. A., Ingham, E. R., et al. (1985): Interaction of bacteria, fungi, and their nematode grazers, effects on nutrient cycling and plant growth. Ecological Monographs 55: 119-140.

[18] ISRIC (1995): Procedures of Soil Analysis. Technical Paper 9. - International Soil Reference and Information Certre, FAO-UN: 9.1-9.13.

[19] Jiang, J., Wu, L., Li, N., et al. (2010): Effects of multiple heavy metal contamination and repeated phytoextraction by Sedum plumbizincicola on soil microbial properties. European Journal of Soil Biology 46(1): 0-26.

[20] Kao, P. H., Huang, C. C., Hseu, Z. Y. (2006): Response of microbial activities to heavy metals in a neutral loamy soil treated with biosolid. - Chemosphere 64(1): 63-71.

[21] Khan, K. S., Xie, Z. M., Huang, C. Y. (1998): Effects of cadmium, lead, and zinc on size of microbial biomass in red soil. - Pedosphere 8(1): 27-32.

[22] Leita, L., Nobili, M., Muhlbachova, G., et al. (1995): Bioavailability and effects of heavy metals on soil microbial biomass survival during laboratory incubation. - Biology and Fertility of Soils 19(2-3): 103-108.

[23] Li, Y. T., Becquer, T., Dai, J., et al. (2009): Ion activity and distribution of heavy metals in acid mine drainage polluted subtropical soils. - Environmental Pollution 157: 12491257.

[24] Li, Q., Jiang, Y., Liang, W. J. (2006): Effect of heavy metals on soil nematode communities in the vicinity of a metallurgical factory. - Journal of Environmental Sciences 18(2): 323-328.

[25] Liao, J. B., Wen, Z. W., Ru, X., et al. (2016): Distribution and migration of heavy metals in soil and crops affected by acid mine drainage: public health implications in Guangdong Province, China. - Ecotoxicology and Environmental Safety 124: 460-469.

[26] Liu, B. B. (2012): Studies on the Characteristics of Soil Nematodes Community by Several Different land Use Types in Jiangsu Province. - NanJing Agricultural University, Nanjing (in Chinese). 
[27] Martinez, J. G., Torres, M. T., dos Santos, G., et al. (2018): Influence of heavy metals on nematode community structure in deteriorated soil by gold mining activities in Sibutad, southern Philippines. - Ecological Indicators 91: 712-721.

[28] Ministry of Natural Resources (2018): China Mineral Resources. - Geological Publishing, Beijing (in Chinese). http://www.yueyang.gov.cn/lxzfw/24733/24760/24821/24864/26888/content_1462180.ht $\mathrm{ml}$.

[29] Nagy, M., Bakonyi, G., Bongers, T., et al. (2004): Effects of microelements on soil nematode assemblages seven years after contaminating an agricultural field. - Sci. Tot. Environ. 320: 131-143.

[30] Nelson, D. W., Sommers, L. E. (1982): Total Carbon, Organic Carbon, and Organic Matter. - In: Page, A. L. (ed.) Methods of Soil Analysis, Part 2. $2^{\text {nd }}$ Ed. American Society of Agronomy, Madison, WI, pp. 539-79.

[31] Popovici, I. (1992): Nematodes as indications of ecosystem disturbances due to pollution. - Stud Univ Babes-Royal Biol 37(2): 15-27.

[32] Porazinska, D. L., Duncan, L. W., McSorley, R., et al. (1999): Nematode communities as indicators of status and processes of a soil ecosystems influenced by agricultural management practices. - Applied Soil Ecology 13: 69-86.

[33] Park, B. Y., Lee, J. K., Ro, H. M., et al. (2011): Effects of heavy metal contamination from an abandoned mine on nematode community structure as an indicator of soil ecosystem health. - Applied Soil Ecology 51: 17-24.

[34] Pennanen, T., Frostegard, A., Fritze, H., et al. (1996): Phospholipid fatty acid composition and heavy metal tolerance of soil microbial communities along two heavy metal-polluted gradients in coniferous forests. - Applied and Environmental Microbiology 62(2): 420-428.

[35] Qiu, L. J., Huang, G. L., Shuai, Q., et al. (2015): Reconstruction of the Conversion Relationship between Organic Matter and Total Organic Carbon in Calcination Method and its Application in Shale Analysis. - Rock and Mineral Analysis 34(2): 218-223 (in Chinese).

[36] Savin, M. C., Gorres, J. H., Neher, D. A. et al. (2001): Uncoupling of carbon and nitrogen mineralization: role of microvorous nematodes. - Soil Biology and Biochemistry 33: 1463-1472.

[37] Shu, X. H., Zhang, Q., Lu, G. N., et al. (2018): Pollution characteristics and assessment of sulfide tailings from the Dabaoshan mine, China. - International Biodeterioration \& Biodegradation 128: 122-128.

[38] Singh, J. S., Gupta, V. K. (2018): Soil microbial biomass: a key soil driver in management of ecosystem functioning. - Science of the Total Environment 634: 497500 .

[39] Thakura, M. P., Del Real, I. M., Cesarz, S. (2019): Soil microbial, nematode, and enzymatic responses to elevated $\mathrm{CO}_{2}, \mathrm{~N}$ fertilization, warming, and reduced precipitation. - Soil Biology and Biochemistry 135: 184-193.

[40] Wang, C. L., Dong, Z. C., Xia, X. Q. (2012): Soil contamination by heavy metals in jinan city and its biological characteristics. - Geology in China 39(03): 818-826.

[41] Wang, G. B., Lu, L., Wei, G. L., et al. (2016): Analysis and evaluation of heavy metal pollution for water and soils in Dabaoshan sewage irrigation area. - Environmental Science \& Technology 39(S2): 444-448 (in Chinese).

[42] Wang, X. L., Xu, J. M., Yao, H. Y., et al. (2003): Effects of Cu, Zn, Cd and Pb compound contamination on soil microbial community. - Acta Scientiae Circumstantiae 23(1): 2227 (in Chinese).

[43] Weiss, B., Larink, O. (1991): Influence of sewage sludge and heavy metals on nematodes in arable soil. - Biology and Fertility of Soils 12: 5-9. 
[44] Wen, Y. F., Zhao, J. Q. (2008): Effect of grazing on soil fertility and phosphorus availability in the red soil region, Northeast Yunnan. - Acta Pedologica Sinica 45(3): 569-572 (in Chinese).

[45] Wu, S., Cheng, J. L., Xu, X. Y., et al. (2019): Polyploidy in invasive Solidago canadensis increased plant nitrogen uptake, and abundance and activity of microbes and nematodes in soil. - Soil Biology \& Biochemistry 138.

[46] Xiao, Y., Xie, G. D., An, K. (2003): The function and economic value of soil conservation of ecosystems in Qinghai, Tibet Plateau. - Acta Ecologica Sinica 23(11): 2367-2376 (in Chinese).

[47] Yang, M. L., Ma, Y. H., Huang, W. X. (2019): Study on the correlation between available state, total amount and $\mathrm{pH}$ of Soil $\mathrm{Cd}$ and $\mathrm{Pb}$. - Guangdong Agricultural Sciences 46(4): 74-80.

[48] Yang, X., Xue, C., Su, L. X., et al. (2018): Exploring patterns of < Italic > Camellia </Italic > seed cake application in relation to plant growth, soil nematodes and microbial biomass. - Soil Science \& Plant Nutrition 64(2): 253-264.

[49] Yu, S., He, Z. L., Zhang, R. G., et al. (2003): Soil basal respiration and enzyme activities in the root-layer soil of tea bushes in a red soil. - Chinese Journal of Applied ecology 14(2): 179-183 (in Chinese).

[50] Zang, Y. F., Hao, M. D., Zhang, H. Q., et al. (2015): Effects of wheat cultivation and fertilization on soil microbial biomass carbon, soil microbial biomass. - Acta Ecologica Sinica 35(05): 1445-1451.

[51] Zhao, H. R., Xia, B. C., Fan, C., et al. (2012): Human health risk from soil heavy metal contamination under different land uses near Dabaoshan mine, Southern China. - Science of the Total Environment 417-418: 45-54.

[52] Zhou, J. M., Dang, Z., Situ, Y. et al. (2004): Distribution and characteristics of heavy metals contaminations in soils from Dabaoshan mine area. - Journal of AgroEnvironment Science 23(6): 1172-1176 (in Chinese).

[53] Zhou, J. M., Dang, Z., Cai, M. F., et al. (2007): Soil heavy metal pollution around the Dabaoshan mine, Guangdong Province, China. - Pedosphere 17(5): 588-594.

[54] Zhuang, P., McBride, M. B., Xia, H. P., et al. (2009): Health risk from heavy metals via consumption of food crops in the vicinity of Dabaoshan mine, South China. - Science of the Total Environment 407: 1551-1561.

[55] Zhuang, P., Li, Z. A., Zou, B., et al. (2013): Heavy metal contamination in soil and soybean near the Dabaoshan mine, South China. - Pedosphere 23(3): 298-304. 